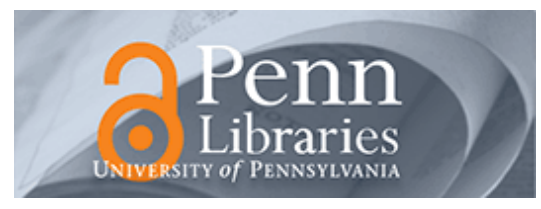

Studies in Visual Communication

Volume 5

Issue 1 Fall 1978

Article 2

1978

\title{
On the Vicissitudes of the Self: The Possessed Dancer, the Magician, the Sorcerer, the Filmmaker, and the Ethnographer
}

Jean Rouch

Recommended Citation

Rouch, J. (1978). On the Vicissitudes of the Self: The Possessed Dancer, the Magician, the Sorcerer, the Filmmaker, and the Ethnographer. 5 (1), 2-8. Retrieved from https://repository.upenn.edu/svc/vol5/iss1/2

This paper is posted at ScholarlyCommons. https://repository.upenn.edu/svc/vol5/iss1/2

For more information, please contact repository@pobox.upenn.edu. 
On the Vicissitudes of the Self: The Possessed Dancer, the Magician, the Sorcerer, the Filmmaker, and the Ethnographer 
among the Songhay-Zarma in certain critical periods.

$\begin{array}{ll}\text { Possession dance } & \text { The character of the possessed person and } \\ \text { of the possessing spirit } \\ \text { The character of the magician and of clair- } \\ \text { voyant states } \\ \text { The character of the tyarkaw ("eater of } \\ \text { Souls") and the character of his victim }\end{array}$

ON THE VICISSITUDES OF THE SELF: THE POSSESSED DANCER, THE MAGICIAN, THE SORCERER, THE FILMMAKER, AND THE ETHNOGRAPHER'

\section{JEAN ROUCH}

\section{TRANSLATED BY \\ STEVE FELD AND SHARI ROBERTSON}

This essay is based, on the one hand, on knowledge about the Songhay-Zarma, at the loop of Niger, which I have gathered over a period of 30 years of ethnographic research. On the other hand, it is based on experimentation with direct cinema, deriving from the theories, under the name cinéma-vérité, prophesized in 1927 by the Russian filmmaker Dziga Vertov. I have used direct cinema as a special research tool in doing ethnography among these same West African groups.

If the notion of "personne" - the self, person-is effectively one of the key religious factors involved in trance, possession dance, magic, and sorcery, it appears that it would be dishonest to leave the matter there, since the "self" of the observer who attends to these phenomena equally merits critical attention. This is especially so when the observer records and plays back the sounds and visual images for the subjects of these trances; those filmed consider these images to be a reflection of themselves and of their divinities; that is, part of the "self" of both men and gods.

This article is intended as a contribution to "shared anthropology." 2 First I will try to point out, within the limits of present knowledge, the concepts of the "self"

Jean Rouch is an ethnographer and filmmaker. He has lived extensively in West African communities of Mali, Chana, and Niger, and has published many ethnographic studies, including La Religion et la Magie Songhay (Paris: Presses Universitaires de France, 1960). He has made over 30 ethnographic films since 1948, and was instrumental in organizing the Comité International des Films de I'Homme (CIFM). Currently he is a director of research in the French Centre National de la Recherche Scientifique, teaches cinema and social science at the University of Paris, and is secretary-general of the Comité du Film Ethnographique of the Musée de l'Homme. Four of his films, Les Maltres Fous (1955), Jaguar (1954-67), La Chasse au Lion à L'Arc (1965; English title The Lion Hunters), and Chronique d'un Été (1960; in collaboration with Edgar Morin), are available in the United States.

Steve Feld and Shari Robertson do research at the Anthropology Film Center, Santa Fe.
After this I will show how the filmmaker-observer, while recording these phenomena, both unconsciously modifies them and is himself changed by them; then how, when he returns and plays back the images, a strange dialogue takes place in which the film's "truth" rejoins its mythic representation. Finally, this demonstration of the active, involuntary role played by the observer will lead me to attempt to get closer to the situation of the ethnographer in his own field.

\section{THE "SELF" IN POSSESSION DANCE}

A previous international colloquium of the Centre National de la Recherche Scientifique provided us with an occasion to review research on possession phenomena. It seems that even though we now have a baseline of complete information about different manifestations of possession in the world-and particularly in Sub-Saharan Africa-it is still not possible to establish a precise typology or sketch out a satisfactory theory. However, it now appears that the phenomenon of trance (whether wild or controlled) is one of the essential features in the momentum behind great religious movements, and, perhaps, behind great movements in artistic creativity. For example, schools of theater have, for 20 years, utilized ethnographic information about possession in order to extract methods applicable for training actors (e.g., Julian Beck and the Living Theatre, Peter Brooke, Roger Blin, and Grotowski).

In the present work I will not go back over the particular mechanics of Songhay possession but rather will deal with the metamorphosis in "the person" or "self" of the possessed subject and of the spirit which possesses him or her. It is enough to note that in this region of the Niger valley possession is a means of special reciprocal communication between people and their gods.

The possessed, the "horses of the spirits," are largely women and are specialists who enter into a recognized group after a long and difficult initiation. After that, they are involved in "wild trances," which treat the sick excluded from the society. These trances are run by priests (zimas) and take place only during public ceremonies regularly organized by and for the entire society.

Some hundred divinities form the pantheon that reveals itself here. These gods are invisible, but they appear as men. They are of different races, have particular characteristics, and are special "masters" (of water, wind, bush, thunder, rainbow, etc.) from complicated legends which make up a very diverse mythology, one that continually reenriches itself with each new ritual and revelation.

After the initiation, each dancer is a "horse," reserved for one or sometimes several "horsemen," who will mount her (sometimes a male) during the trance and for 
minutes or hours "operate" the body and speak through the mouth of the "horse." For the Songhay-Zarma, contrary to other neighboring systems, it is this dialogue with the gods that is the essential aim of possession ceremonies. There is thus a profound metamorphosis of the "self" of "the horse," who gives up a part of herself to a part of the "self" of the god who is now incarnated in her body.

While observation of possession phenomena is easy because of the essentially public character of the ceremonies, interpretation is much more delicate because, for the Songhay-Zarma, the possessed person does not, at least theoretically, have a single memory of the trance and resists all allusion to the possessing god. Of course, while in a normal state herself, she has seen others possessed, but this does not seem to influence her.

The sources of information are thus limited to the zimas; they are responsible for the initiation, become possessed themselves, and have acquired control over the possession of others. (I have sometimes tried to question the gods themselves through the "horse" during possession, but this technique seemed to be both singularly dangerous and, all things considered, too incoherent.) The most widespread theory propounded by the zimas is that during possession the "double" (bia) of the god has taken the place of the "double" of the "horse." It is this exchange of "doubles" that I would like to analyze.

The notion of bia itself is very fuzzy, designating at the same time "shadow" (it literally means "somber"), "reflection" (in a mirror or pool of water), and "soul" (spiritual principle of all animate beings). This bia is tied to the body throughout life; it can temporarily leave the body during sleep (in dreams) or, occasionally, while awake (in a state of imagination, reflection, or possession). It leaves the body at the moment of death to follow its own course in the hereafter. Curiously, some people locate this "double" a bit to the rear of the body, on the left side (when dreaming, one must sleep on the right side); it is here that the possessing god temporarily comes to place himself or his "double."

Do invisible gods, in effect, merely have a "double" or are they themselves a "double"? The question must rest there, because in certain circumstances (for the important zimas) these gods can materialize and show themselves in human form (thus having or not having a bia, shadow, reflection, double).

It appears, however, that possession is only the affair of the gods, but even at this level of the "double," the phenomena of possession merit careful attention. I have attended several hundred possession ceremonies (I have filmed about 20) and have been able to observe, under the best conditions, this strange metamorphosis of trance and vertigo. It begins with the apparent loss of consciousness and is followed by the slow appearance of a new character, first trembling and howling, then becoming calm. Then the behavior takes on another manner, manifested by speaking in another voice and sometimes in another language. Once one is accustomed to the repertoire of personnages, immediate identification is possible: it is Dongo, the spirit of thunder, or Zatao, the captive of the Peul people.
In January-February 1971, after making and showing my film Horendi, which concerns the seven days of initiation into possession dance, a group of musicians, zimas, and sorko fishermen brought out some important data about the metamorphosis of "self" in the possession state. These are the principal traits:

It is the left hand of the bowed lute (godye) player that is "inspired" (driven) by the spirits who are collectively called out at the beginning of the ceremony by "the air of the hunters" (gawey-gawey). The drummers, playing on calabashes or skin drums, follow the play of the left hand, and the vibration of bass notes gives "power" to the dancer. It is also in the left hand that the lute player expresses the first sign of the arrival of the spirit in the dancer's body. He kicks the drummer in front of him, who in turn accentuates the rhythm; this accelerates the power of the dancer and "reinforces" the spirit that has begun to straddle him.

What is happening with the dancer? Following numerous indirect accounts (it has already been noted that the dancer is not supposed to remember his state), the dancer "sees" the spirit penetrate into the dance circle and direct himself toward him. Occasionally the important initiates see him too. The spirit has in his hands the skin of a freshly sacrificed animal, which he holds out with the bloody side toward the dancer. He offers it three times. The first time the dancer's eyes tear. The second time the dancer's nose runs. The third time the dancer howls. If several "horses" of the same spirit appear in the course of the dance, they all will see him, and they can all have the same reaction simultaneously. However, only one selection is made during the three provocations.

After this, the spirit approaches a fourth time and retrieves the bloody skin from the head of the dancer. The dancer chokes-it is the climax of the ceremony. At this point the spirit embodies the "double" of the dancer and takes the double's place. The dancer is now "mounted on his or her horse"; that is, the dancer is possessed. During the entire period of the possession the bia, or "double," remains enclosed and protected, particularly against witches, by the bloody skin. When the spirit wants to leave, the skin is lifted, liberating the bia. When this happens the "horse" opens his eyes, is dazzled, coughs as if having been strangled, and snorts in order to remove the traces of the bloody skin from his face.

The Songhay theory of the person in the possession state thus involves three elements:

1. A temporary substitution of the "double" of the person by the "double" of a spirit or by a spirit himself.

2. The preservation of the substituted "double" in a protective fresh skin.

3. The role of music and dance in calling the spirit into incarnation.

\section{THE "SELF" OF THE MAGICIAN}

Contrary to the case of possession dance, where through the intermediary of a "horse-medium" men can communicate directly and publicly with their gods, the case of magic is different. Here, it is a question of an indirect and private consultation with invisible forces, in 
which the magician, all alone, performs a special and difficult role.

The magician (sohantye) is a descendant, through his father, of Sonni Ali, the Si, founder of the Songhay empire. $\mathrm{He}$ is chosen and initiated by his parent or by a more skilled master who is trained in the difficult exercise of permanent contact with invisible forces. He cannot practice his art until after the death of his father (or of his initiator), for it is at this time that he swallows a small initiation chain, which he in turn will vomit up several days before his death. The magician has a solitary and distant personality. He is feared but indispensable. A master of gestures and words, of trees and stones, he is guardian of the spiritual order of the village, and capable of reconciling the spirits with men who dare ask it. These permanent "seers" are, without an intermediary, the masters of their "doubles." They are sent in the form of vultures to encounter allied spirits and to reconnoiter through space and time the course of certain enterprises.

One consults a magician with a certain reticence, and only under grave conditions, because once his action commences, it is hardly ever possible to reverse it. Misfortune without recourse befalls the imprudent person who goes astray on the dangerous routes of the invisible. The consultation is long and difficult. The magician must take all precautions, study his client, and discover the unacknowledged purpose involved. After several days of consultation, he may stop short and reconsider if an awkward gesture or word revealed any deceit in the actual transaction.

Whether divination is involved (by either throwing of cowries or direct prophecy) or the preparation of a magical charm (korte), the procedure is always the same. By his words and movements, the magician converts his "double" and sends him to gather the necessary materials for his work. Or he simply projects his "double" by the side of the "double" of the client in order to find out things that the client has not said or may not even be aware of.

The recited texts (which I have discussed at length elsewhere) are quite extraordinary. The magician first locates himself spatially, in relation to the six cardinal directions, and then situates himself in respect to his initiation chain. The identifying text is said in a loud voice, which both strengthens the magician himself and gives his bia the necessary energy to undertake the "path," or voyage.

As Luc de Heusch has correctly noted, it is more important for a shamanistic act than for a possession phenomenon to be disguised. Thus the recited texts are accounts of the dangerous voyage; they convey how the "double" of the magician confronts the "double" of both beneficial and evil spirits, confronts the "doubles" of other magicians who try to destroy his work, and, above all, confronts the "double" of the demiurge Ndebi, and of god himself. Through his "double" the magician must triumph in successive tests, emerging superior to all other forces encountered. Throughout he does not require the assistance of these secret powers; rather the "double" should be able to compel them to actualize what the magician has asked. Then, when all has been decided, the "double" returns, following the reverse route, ending up next to the magician, who has never lost control of it.

This brief but total power sometimes manifests itself in a dramatic public way, during the festival of magicians (sohantye hori). For the occasion of a circumcision, the gossi (an ancient initiation of young girls) or, more simply, for the purification of a village, the sohantye will all come together for a festival. The magicians dance to the rhythms of the hourglass drums, brandishing in one hand a sabre (lolo) to lance or pierce the "doubles" of sorcerers, and in the other, a branch from a euphorbia plant.

This dance is a dramatic mime of a fight with the forces of evil. The magicians dance continually until the moment when one who feels himself to be the strongest enters into a trance. This trance has little in common with the state of possession previously described; the magician trembles violently, and then up from his mouth gushes a piece of the metallic chain that he swallowed at the time of his father's (or initiator's) death. This initiation chain is, in fact, his "superior identity," inasmuch as it materialized from his initiated ancestors. During the short time that the chain is visible the bia of the magician, in the form of a vulture, quickly accomplishes its journey to the land of the spirits and their "doubles." The purpose of the voyage is to discover, then wipe out, the causes of impurity in the village. The risk involved here is considerable: if an enemy or rival has more power than the magician who has spit up his chain, the former can hinder the reswallowing. This would effectively prevent the retreat of the magician's "double," who, as a result, would die from the loss of his essential source (the chain).

Based on the above description, one can sketch out a Songhay theory of the "self" of the sohantye, or magician:

1. The "double" leaves the body of the magician, but without substitution by another "double" (as in possession).

2. This "double" undertakes a dangerous voyage among spirits and invisible forces.

3. The magician's speech (or the music of the drumming griots) and his special gestures (or ritual dance) are the underlying driving forces behind the shamanistic voyage.

4. Communication with other men is made by the material preparation of charms, by direct prophecy, and by the dramatic exhibition of the chain.

5. The voluntary projection of the "double" can be accompanied by mortal risk.

\section{THE "SELF" OF THE TYARKAW, THE "SORCERER-SOUL EATER"}

The sorcerer (tyarkaw) is much like the magician, but instead of using his or her power to defend or guide other men, the sorcerer uses it to work evil, causing the death of victims by stealing "doubles."

The power of the sorcerer, like that of the magician, is inherited through mother's milk —an infant nourished by a tyarkaw will become a tyarkaw. Songhay mythology emphasizes this irremediable character. Once upon a time, a sacred woman, responsible for a community of women as a result of having made a vow of chastity, yielded to a visitor who spent the night with her. The next morning she changed him into a sheep. Her companions 
in turn asked permission to eat this mysterious animal; as they did, the woman ate also. Thus she was pregnant by a man whom she helped eat. From this union of a woman and a man she had eaten, a child was born-a female "eater of doubles," a tyarkaw. From this tyarkaw all other sorcerers descend.

Since that mythic time each Songhay village contains a fairly large number of tyarkaw. Of course everybody knows who they are, but nobody speaks about it. Tyarkaw work evil because they are obligated to do so; in actuality they are criminals, but, from the Songhay point of view, their criminality is not intentional. This mysterious system can only be comprehended by means of the concept of the "self," or "personne," of the tyarkaw; but inquiries about these people are so risky that they are almost impossible.

Like the magician, the sorcerer has the skill to direct its "double"; and it is the "double" who is in fact the actual agent of the sorcery. The "double" performs the task of hunting other "doubles." Often at night near certain villages, one perceives from the bush visions of rapidly moving fires, which stop and start up again in successive bounds. These suspicious lights, whose explanation is not clear, are interpreted as tyarkaw roaming about. In effect, these sorcerers have the power to propel themselves through the air owing to fire that is emitted from their armpits and anuses. The few inquiries that I have been able to make indicate that the sorcerer's "double" is responsible for these manifestations; in other words, it is the moving about of the "double" that is perceived in the form of the fire movements. Meanwhile, at the same time, the body of the sorcerer is at home in the village, "in a state of deep meditation."

The flashing "double" can self-metamorphose into a calabash, a crying baby, or a donkey with two headsforms it takes in order to frighten its future victim. While flying, the tyarkaw double sees a delayed traveler; the "double" successively turns itself into these three forms along the road, and, should the traveler pick up the calabash, touch the baby, or strike the donkey with two heads, misfortune befalls him. He lapses into a state of panic and fear, losing his reason and hence the control of his own "double." At this point, the tyarkaw's "double" seizes the "double" of the victim and eats it. Once his body is empty of its "double," the victim returns to the village, stupefied. If after seven days no one has returned his "double," he dies.

One of the basic functions of the magicians is to engage in combat with the sorcerers and force them to return stolen "doubles" before they are eaten. This involves a strange kind of fight- "double" against "double," while each corresponding person has his intact body lying in a corner of his house.

The accounts of these imaginary combats are fabulous. Armed with a lolo lance, the magician tries to prick the tyarkaw, who defends himself by throwing millet stalks. At dawn, when the "doubles" rejoin their respective bodies, they are marked with the wounds they received, swollen scars which they proudly exhibit. But never does the fight otherwise prolong itself in reality. The magician never asks about the actual sorcerer (who might very well be a neighbor). The only exception here is when the sorcerer has overstepped his or her bounds, by attacking either the children of the sohantye or those taken in by his family. If this happens, the sohantye takes a lolo and pierces the tyarkaw, forcing him or her to defecate the "egg of power." This fight of "doubles" does materialize into reality; the sorcerer is deprived of the "egg" which the sohantye uses in order to concoct charms for his defense. (This allusion to an "egg of the witch" appears generally throughout the savannah of West Africa and deserves systematic study.)

But, all this notwithstanding, what becomes of the "double" of the victim, his stolen soul? Mysteriously passive and defenseless, the "double" is "hidden" (or perhaps pierced by a lolo) over the course of seven days. At the end of this period, the sorcerer leaves in the form of an owl to share his hunted "double" with other sorcerers who belong to the same "society." (This concept is analogous to the "diabolical societies" found along the West African coast.) Alternatively, it is given to his protecting spirit, himself a sorcerer. The "double" is then "eaten" by one or the other and the victim dies.

While apparently logical, this scheme is nonetheless insufficient. For example, there are several things it does not explain:

1. The personal benefit the sorcerer or the society derives from his risky acts. Is it accumulation of power? How? And for what?

2. The particular role-benevolent or malevolent-of the sorcerer in the society where he or she also acts in a vulnerable manner.

The fate of the "double" (in principle, immortal) of the victim after death. Does the double change into something else? Is the double reincarnated? Or surrendered following some particular use in the world of "doubles"? Does the double become a spirit? If so, he could become an originator of other myths.

4. The total immunity of certain people from their village tyarkaw. The tyarkaw are known by all but tacitly ignored. In some villages, for example, where there are many known sorcerers, young men avoid marrying their daughters. These women then either exile themselves or become courtesans.

In-depth studies of these questions are evidently quite difficult but obviously necessary; a phenomenon so widespread must hold an essential key to systems of thought in Sub-Saharan Africa. For the moment I must refrain from applying to the sorcerer-victim relationship an eventual Songhay theory of the "self" of the sorcerer. As for the rest of the data:

1. The "double" leaves the body of the sorcerer and as in the case of the magician, no other "double" can take its place.

2. This "double" undertakes a hunt for the "doubles" of other men. It separates them from their bodies by fright. This offensive is, in some ways, comparable to the process of the spirit brandishing the bloody skin in front of the dancer at the moment of possession.

3. No "double" can be substituted for the victim, who quickly regains consciousness. He is thus like the sorcerer in body but incapable of recovering, as is the sorcerer, his spiritual principle.

4. The appearance for the first time of the death of the "double" (and consequently his body) as the result of prolonged separation.

5. The existence of a potential world where the "doubles" of living men associate with the "doubles" of spirits (or with the spirits themselves). In this world they encounter themselves, fight with or mutually assist one another, thus sharing a secret collective imagination (in contrast to possession dance, where this collective imagination is publicly witnessed.) 


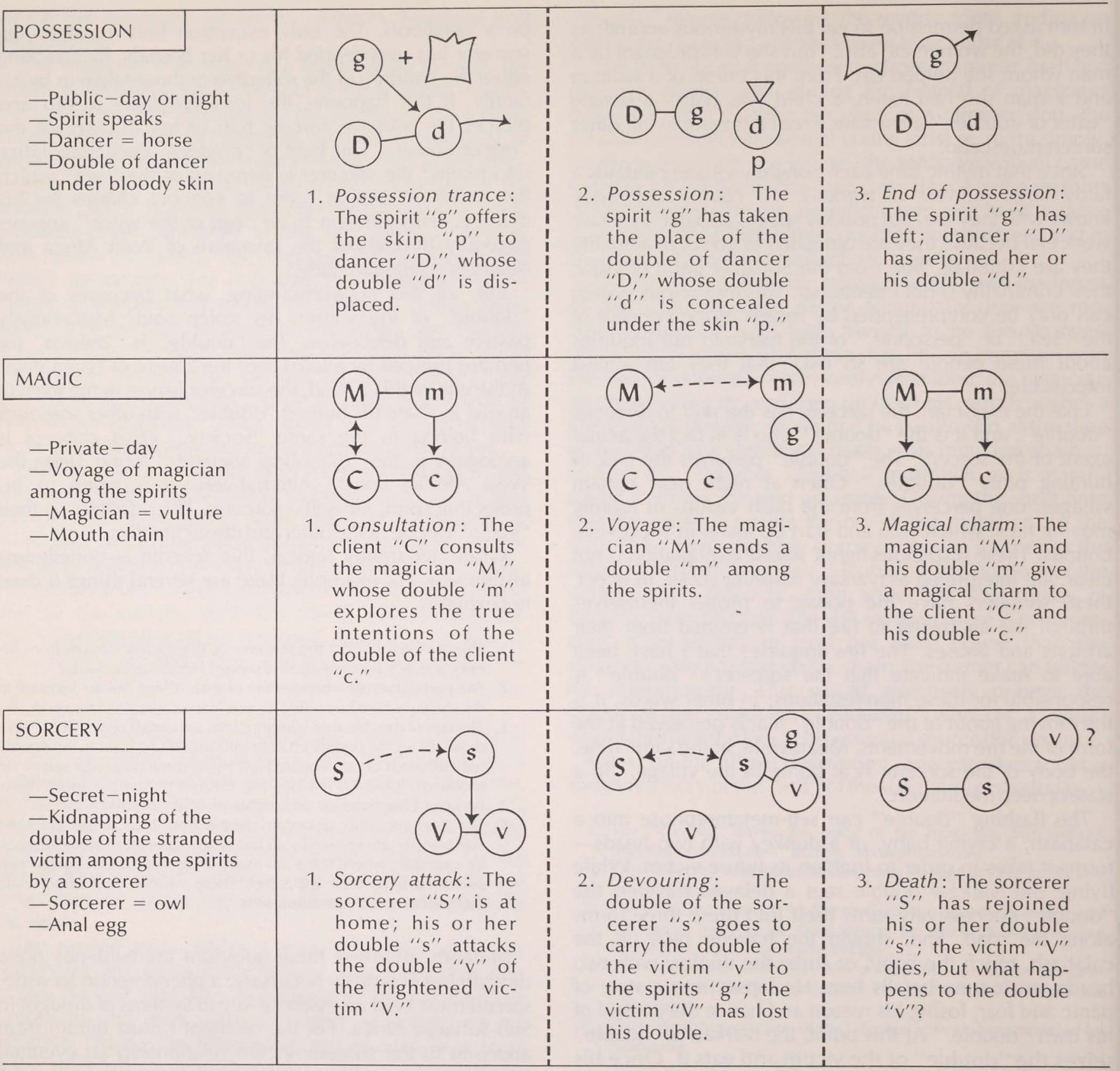

6. The singular economy of the "doubles" of victims-consumed, exchanged, or destroyed - is an area whose key remains to be discovered.

7. The forced production of an anal egg, in which is concentrated the sorcerer's power (this again contrary to the magician, who voluntarily spits up his chain).

Before dealing with the other side of the observation process (by the ethnographer-filmmaker), it might be useful to review and summarize the points concerning the notion of bia, the "double."

Each man has a bia, or "double," who lives in a parallel world, that is, a "world of doubles." This "world" is the home of the spirits, the masters of the forces of nature; it is also the permanent home of the imaginary (dreams, reveries, reflections) as well as the temporary home of magicians and sorcerers. This reflection world does not seem to extend beyond the limits of the earthly world, and, in particular, does not overlap with the world of the hereafter managed by god.

Between the real world and its "double" certain connections are possible, whether by the incarnation of spirits during possession dances, by shamanistic incursion of magicians into the reflection world, or by the materialization of a sorcerer at the time of his hunt for other men's "doubles."

These two worlds, finally, are so completely interpenetrated that it is nearly impossible for the noninformed observer to distinguish the "real" from the "imaginary." For example, the statement "I met Ali yesterday" can mean equally "I actually met Ali yesterday" or "I 
dreamed or I thought I met Ali yesterday." And when the observer is first thrown into this exercise, he can disturb or upset both the "real" and the "imaginary."

\section{THE "SELF" OF THE OBSERVER AND PARTICULARLY OF THE ETHNOGRAPHER-FILMMAKER}

In this world of fragile mirrors, standing beside men and women for whom any clumsy action may provoke or inhibit trance, the observer's presence can never be neutral. Whether he wishes it or not, the observer himself is integral to the general movement of things and his most minute reactions are interpreted within the context of the particular system of thought that surrounds him.

I have chosen here to begin with the "self" of the filmmaker because recording and then projecting images and sounds introduces a concrete element which books-even illustrated ones-leave out. This is so because the people we study are in large part nonliterate but do know how to look and listen. Over the years technical advances have resulted in increasingly complex equipment whose operation is increasingly simple. This has led to the use of direct cinema-that is, the synchronous recording of image and sounds - as a tool of ethnographic observation. Since the making of several film studies in Dahomey and Mali, in collaboration with Gilbert Rouget and Germaine Dieterlen, during the period 1957-1965, I have systematically used this technique.

The two pioneers of the technique of direct cinema were the American Robert Flaherty and the Russian Dziga Vertov; during the 1920s they invented the notions of the "participating camera" and of "cinéma-vérité." Just when the first theoreticians of film tried to define this new "language" in relation to fiction (coming directly from the theatrical tradition), Flaherty and Vertov turned their barely outlined rules upside down by experimenting with cinema in real life.

Dziga Vertov understood that cinematic vision was a particular kind of seeing, using a new organ of perception-the camera. This new perception had little in common with the human eye; he called it the "ciné-eye." Later, with the appearance of sound film, he similarly defined the "radio-ear," a new special organ of recorded hearing. Extending his analysis we know today that this new kind of audio-visual language can be understood (I should say "ciné-compris," or "film-understood") by audiences with no special education. He called the entirety of this discipline "kinopravda" - (cinéma-vérite, or "film-truth"), an ambiguous or self-contradictory expression since, fundamentally, film truncates, accelerates, and slows down actions, thus distorting the truth. For me, however, kinopravda (cinéma-vérité) is a precise term, on the same order of kinok (ciné-eye), and it designates not "pure truth" but the particular truth of the recorded images and sounds-a filmic truth (ciné-vérité).

At every stage of direct cinema, a film attitude (cinéattitude) manifests itself. Contrary to scripted fiction films, the direct-cinema filmmaker must be ready at every moment to record the most efficacious images and sounds. To return to the terminology of Vertov, when I make a film I "film-see" (ciné-vois) by knowing the limits of the lens and camera; likewise, I "film-hear" (cinéentends) in knowing the limits of the microphone and tape recorder; I "film-move" (ciné-bouge) in order to find the right angle or exercise the best movement; I "filmedit" (ciné-monte) throughout the shooting, thinking of how the images are fitting together. In a word, I "filmthink" (ciné-pense).

Robert Flaherty, a rough Irish-American geologist, used a camera for the first time in the far North among the Hudson Bay Eskimos. He was unaware of these theories, and did not need them, although he had to solve similar problems in the field. From the very start he applied an extraordinarily empirical technique by allowing the Eskimos, Nanook and his family, to participate (beyond acting) in his film, Nanook of the North. Under incredible field conditions Flaherty accomplished this kind of participation by building a location development laboratory and projection room. In doing so, he invented the use of the "participating camera," a technique that he saw not as an obstacle to communication but, on the contrary, as an indispensable part of filmmaking in the field.

I have been more or less consciously synthesizing and applying these two methods to my own work in ethnography. Today all the people I film know the camera, and they clearly understand its capability to see and hear. They have helped me during the editing process by screening projections of my films; in Vertov's terms, at the time of shooting they are "film-seen" (ciné-vus) when I "film-observe" (ciné-regarde) them. In fact, they react to this art of visual and sound reflection in exactly the same manner as they react to the public art of possession or the private art of magic or sorcery.

Long ago, Frazier, in The Golden Bough, noted the frightened reaction of "primitives" to being photographed; the reflection might endanger their souls. What does this imply about the moving image, in color, with sound? It is only necessary to have once attended the projection of such a film in the field to understand this kind of emotional shock. One year after its making, I showed my film, Sigui 1969-La Caverne de Bongo, to the villagers of Bongo, in Mali, where I shot it. Animated by a piece of celluloid, they relived a past timereflections of disappeared people, phantom impressions that one sees, that one hears but does not see, or that one does not hear.

I now believe that for the people who are filmed, the "self" of the filmmaker changes in front of their eyes during the shooting. He no longer speaks, except to yell out incomprehensible orders ("Roll!" "Cut!"). He now only looks at them through the intermediary of a strange appendage and only hears them through the intermediary of a shotgun microphone.

But, paradoxically, it is due to this equipment and this new behavior (which has nothing to do with the observable behavior of the same person when he is not filming) that the filmmaker can throw himself into a ritual, integrate himself with it, and follow it step by step. It is a 
strange kind of choreography, which, if inspired, makes the cameraman and soundman no longer invisible but participants in the ongoing event.

For the Songhay-Zarma, who are now quite accustomed to film, my "self" is altered in front of their eyes in the same way as is the "self" of the possession dancers: it is the "film-trance" (ciné-transe) of the one filming the "real trance" of the other. This experience is really true to me, and I know by the control of my camera eyepiece, by the reactions of the audience, whether the filmed sequence is a success or a failure and whether I have been able to free myself of the weight of filmic and ethnographic theories necessary to rediscover the "barbarie de l'invention."

One can even take this further: Isn't the "image-hunt" comparable to the sorcerer's "hunt for doubles"? And the material that I take such extraordinary care of-the film, keeping it in darkness, dry, at a low temperature-is it not just a "reflection package," a "package of doubles"? If the camera can be compared to the bloody skin of the possessing spirit, then the shipment of the film to the distant processing laboratory can be compared, by contrast, to the devouring of the double by the sorcerer.

The analogy for me stops there, because the next steps are not explicitly a part of African mythology. The "stolen" image comes back several months later, and when projected on the screen, recovers its life for an instant. The reflection is bestowed with such a strange power that its viewing is enough to make a "horse of the spirit" see itself possessed on the screen and immediately enter into trance.

Currently I am at the point of reflecting on my own role as a taker and giver of "doubles," as an "eater" and "shower" of reflections. I already know that the next step is research to clarify these roles in relation to the "self" of the ethnographer and ethnography itself. For the moment it is hardly possible to establish a Songhay theory of the "self" of the filmmaker, but I will be trying to draw up such a profile in my future work with the priests, fishermen, and magicians who have collaborated with me over the last 30 years.

Nonetheless, I can show a short film which points out the obvious role played by the camera as a stimulant to possession. [At this point in the presentation Rouch's film Tourou was shown. See the Appendix for a description of this film.]

\section{CONCLUSION}

These critical reflections on the "self" of the filmmaker lead me to expand on the concept of the "self" of the ethnographer.

In the field the observer modifies himself; in doing his work he is no longer simply someone who greets the elders at the edge of the village, but-to go back to Vertovian terminology-he "ethno-looks," "ethnoobserves," "ethno-thinks." And those with whom he deals are similarly modified; in giving their confidence to this habitual foreign visitor they "ethno-show," "ethnospeak," "ethno-think."

It is this permanent "ethno-dialogue" which appears to me to be one of the most interesting angles in the current progress of ethnography. Knowledge is no longer a stolen secret, devoured in the Western temples of knowledge; it is the result of an endless quest where ethnographers and those whom they study meet on a path which some of us now call "shared anthropology."

\section{APPENDIX}

\section{Description of the film Tourou}

On March 15, 1971, the Sorko fisherman, Daouda, asked me to come film at Simiri, in the Zarmaganda of Niger. The occasion was a possession dance to ask the black spirits of the bush to protect the forthcoming crop from the locusts.

Despite the efforts of the zima priest Sido, Daouda's father, and despite the use of two special old drums, "tourou" and "bitti," no one became possessed for three days.

On the fourth day I again went to Simiri with Daouda and my soundman, Moussa Amidou. After several hours without possession taking place, I decided to shoot anyway. Night was about to fall, and I thought I would take the opportunity to shoot some footage of this beautiful music, which is in danger of disappearing.

I began to film the exterior of the compound of the zima priests, then, without turning off and on, passed through the pen of the sacrificial goats, and then out into the dance area where an old man, Sambou Albeydu, was dancing without much conviction. Without stopping I walked up to the musicians and filmed them in detail. Suddenly the drums stopped. I was just about ready to turn off when the godye lute started up again, playing solo. The lute player had "seen a spirit." Immediately Sambou entered into the state and became possessed by the spirit kure (the Hausa butcher, the hyena). I kept filming. Then old Tusinye Wazi entered the dance area; she immediately was possessed by the spirit Hadyo. Still without stopping, I filmed the consultation of spirits by the priests - a sacrifice was requested. At this point I began to walk backward, framing a general establishing view of the compound, now flushed with the coming of sunset. The filming was thus one continuous shot, the length of the camera load.

Looking back at this film now, I think that the shooting itself was what unlatched and sped up the possession process. And I would not be surprised if, upon showing the film to the priests of Simiri, I learned that it was my own "ciné-trance" which played the role of catalyst that night.

\section{TRANSLATORS' NOTES}

\footnotetext{
1 Translation of Essai sur les avatars de la personne du possédé, du magicien, du sorcier, du cinéaste, et de l'ethnographe. The paper was prepared for a conference held in Paris, 11-17 October 1971. It was published in the proceedings, La Notion de Personne en Afrique Noire, Colloques Internationaux du Centre National de la Recherche Scientifique, No. 544, 1973, pp. 529-544. For a detailed discussion of the ethnographic materials from Niger, see Jean Rouch, La Réligion et la Magie Songhay, 1960, Paris: Presses Universitaires de France. A recent popular essay, with photos, on Songhay possession rituals is Dongopluie et foudre au Niger, in Atlas, No. 96, May 1974, pp. 60-83. A general introduction to Rouch's work with cinema is The Camera and Man, in Studies in the Anthropology of Visual Communication, 1(1):37-44, 1974. Our special thanks again to Ms. Marielle Delorme of the Centre National de la Recherche Scientifique for reviewing the translation

${ }^{2}$ Rouch uses the term anthropologie partagée; the concept is similar to what is termed "reflexive anthropology" in the United States.
} 